\title{
ROMANIAN BRAND NOTORIETY AMONG YOUNG PEOPLE
}

\author{
Laura Cătălina Țimiraș \\ "Vasile Alecsandri" University of Bacau \\ timiras.laura@ub.ro
}

\begin{abstract}
Based on the results of a direct research conducted in April 2016 among students of the Faculty of Economic Sciences of the Vasile Alecsandri University of Bacau, this paper highlights the notoriety of Romanian brands in general, as well as for product categories: food products and alcoholic beverages, cosmetics and personal hygiene products, cleaning products, clothing, footwear, consumer electronics and cars. The research was conducted on a sample of 100 respondents aged between 18-30, having an exploratory character. We studied unaided brand awareness, respondents being asked to indicate the top three brands that come to their mind for each evaluated product. The results of the study revealed the most recognized Romanian brands on the investigated sample, both in terms of known brand enunciation among the top three, and as first nominations made (Top-of-mind awareness).
\end{abstract}

\section{Keywords}

direct research; brand; unaided brand awareness; top-of-mind awareness

\section{JEL Classification}

M31

\section{Introduction}

In April 2016 we organized a survey among students of undergraduate studies of the Faculty of Economic Sciences of the Vasile Alecsandri University of Bacau, one of the objectives being to identify the Romanian brand awareness among youth in general and for product categories: food products and alcoholic beverages, cosmetics and personal hygiene products, cleaning products, clothing, footwear, electronics and appliances, cars.

The research among the segment of young people is based on the fact that they usually have different preferences compared to older people in terms of brands / products, given the fact that in the process of self-knowledge, they are very open to new things, even looking for it actively (Pringle \& Field, 2008). On the other hand, according to the same authors, older people are less receptive to novelty (giving as example, music), their tastes acquired during youth may remain unchanged.

In this context, this paper aims to identify how common are Romanian brands to young population, which is in the process of formation, starting from the idea that, as the brand is known and appreciated in this period of life, it has a greater chance to be preferred and later, as the individual ages, in the context of decreasing interest in novelty.

Studying brand involves evaluating several aspects. Thus, Datculescu (2012) states that matters usually covered are: brand awareness, brand knowledge, the general opinion about it, functional performance of the product, image, feelings and emotional states evoked, the extent to which they influence behavior. 
Marketers are very interested regarding consumers' knowledge about brands. Most strategies aim to make consumers aware of a brand, teach them about it, and influence them to buy it (Peter \& Olson, 2008).

Note that from all listed matters, which can be investigated, the paper presents only the information referring to brand awareness.

In the Business Dictionary, brand awareness is defined as "extent to which a brand is recognized by potential customers, and is correctly associated with a particular product. Expressed usually as a percentage of target market, brand awareness is the primary goal of advertising in the early months or years of a product's introduction" WebFinance, Inc. (2016). To make buyers aware of a brand is a prerequisite (but not sufficient) to convince buyers to purchase it (Kotler \& Pfoertsch, 2006).

\section{Methodological issues}

The research was conducted on a sample of 100 young people aged between 18 and 30 , and data collection was performed using questionnaire by self-registration.

Sampling method used was sampling group, from a total number of 9 study groups were selected 4 groups and put under investigation.

We opted for the assessment of brand awareness, asking respondents to indicate the top three domestic brands that come to mind in general, and by product category (unaided awareness).

\section{Limits and value of research results}

The conducted research is exclusively representative for collectivity made up of 1830young students of the Faculty of Economic Sciences of the Vasile Alecsandri University of Bacau (for a probability of 95\% results guarantee and an error of $2.17 \%$ ). The importance of research results comes from the fact that we give a guideline on the awareness of Romanian brands for investigated product categories, the study results could constitute hypotheses for research on representative samples of different communities of young people (from the county, region, country, etc.).

In interpreting the results one should, however, realize that the awareness is only a necessary, but not sufficient, condition for a successful brand, so to have a whole image about the popularity of Romanian brands it's needed to extend research and evaluation on other issues which highlight the performance of a brand.

\section{The research results referring to Romanian brands awareness among youth}

The first aspect considered in the undertaken research was the knowledge of unaided awareness of Romanian brands in general (without taking into account the category of product/service to which it relates). Thus, when asked to indicate the top three domestic brands that come to mind, 86 respondents indicated 3 brands, 9 respondents 2 brands, and 5 of them one brand.

Given the number of respondents who indicated a particular brand among the top three that come to mind, according to Table. 1, the best known Romanian brands are: Dacia - first place, Pambac - second place (both indicated by over 30 respondents), followed by: Agricola - third place, Cotnari - fourth place, Timişoreana - fifth place (indicated by over 10 respondents), Bucegi - sixth place, Napolact and Ursus - both ranked seventh, Ciuc, Farmec, Dedeman - all three ranked eighth, Luca, Glade, Covalact - ranked ninth.

But if we take into account only the first response indicated by respondents, knowing that the best known brand is first mentioned (top of mind awareness), the position 
held by some brands may register differences. Thus, it appears that there are brands which are indicated by a smaller number of respondents among the top three known, but most of them have nominated them "at the forefront" of the list. For example, Farmec, nominated by 6 respondents among the top three known brands, was given the first place by 5 of them, so outpaced brands such Timişoreana, Bucegi, Ursus, Cotnari and Napolact, listed above in higher positions. Similarly, Cotnari brand, located on the fourth position in terms of nominating, is out of the top 10 brands in the country based on the top of mind awareness.

Table 1 shows local brands which were given a position on top by a minimum of 5 respondents. Note that some of the listed brands are not indigenous, but none of them have exceeded a total of five nominations.

Table 1. The most famous Romanian brands*

(Number of respondents who indicated a particular brand among the top three that come to mind)

\begin{tabular}{|l|c|c|c|c|}
\hline Brand & $\begin{array}{c}\text { As first } \\
\text { option }\end{array}$ & $\begin{array}{c}\text { As second } \\
\text { option }\end{array}$ & $\begin{array}{c}\text { As third } \\
\text { option }\end{array}$ & $\begin{array}{c}\text { \% persons who } \\
\text { indicated brand } \\
\text { among the top 3 } \\
\text { known brands in total } \\
\text { number of } \\
\text { respondents }\end{array}$ \\
\hline Dacia & 20 & 7 & 10 & 37 \\
\hline Pambac & 13 & 11 & 10 & 34 \\
\hline Agricola & 6 & 9 & 4 & 19 \\
\hline Cotnari & 1 & 8 & 4 & 13 \\
\hline Timişoreana & 4 & 6 & 1 & 11 \\
\hline Bucegi & 3 & 2 & 4 & 9 \\
\hline Napolact & 1 & 5 & 1 & 7 \\
\hline Ursus & 2 & 1 & 4 & 6 \\
\hline Ciuc & 1 & 3 & 2 & 6 \\
\hline Farmec & 5 & - & 1 & 5 \\
\hline Dedeman & 2 & 1 & 3 & 5 \\
\hline Luca & 3 & 2 & - & X \\
\hline Poiana & 1 & 2 & - & $X$ \\
\hline Covalact & 35 & 38 & 38 & \\
\hline Other answers** & 100 & 95 & 86 & \\
\hline Total answers & 5 & & & 7 \\
\hline
\end{tabular}

* brands indicated by a minimum 5 respondents.

**including non-indigenues brands.

In the following lines are presented the results of research about the unaided awareness of the brands for some product categories, results obtained following the same procedure.

Thus, regarding the food products (excluding alcoholic beverages), 44 respondents indicated 3 brands, 18 respondents 2 brands and 16respondents one brand. Note that $22 \%$ respondents could not indicate any domestic brand of food. The reasons for which about $1 / 4$ of the respondents could not indicate at least one Romanian food brand products may pose a problem to be studied in future research, given the nature of current consumption and thus permanent contact with this product category.

The data presented in the Table. 2 attests that the best known brand of food products is Pambac. It stands out over other brands being in the forefront both in terms of brand nominations as the first option (top of mind) and in terms of the number of nominations among the top three known. 
Second after Pambac, in terms of number of respondents who indicated it among the top three known brand stands Agricola, but is surpassed by Napolact in termsof the indicator top of mind awareness. Other brands of domestic food products, which enjoy a greater awareness among young people are: Poiana, Borsec, Dorna, Rom, Zuzu, Covalact, Luca, Albalact.

Table 2. The most famous Romanian food brands* (Number of respondents who indicated a particular brand among the top three that come to mind)

\begin{tabular}{|l|c|c|c|c|}
\hline \multicolumn{1}{|c|}{ Brand } & $\begin{array}{c}\text { As first } \\
\text { option }\end{array}$ & $\begin{array}{c}\text { As second } \\
\text { option }\end{array}$ & $\begin{array}{c}\text { As third } \\
\text { option }\end{array}$ & $\begin{array}{c}\text { \% persons who } \\
\text { indicated brand among } \\
\text { the top 3 known brands } \\
\text { in total number of } \\
\text { respondents }\end{array}$ \\
\hline Pambac & 24 & 12 & 4 & 40 \\
\hline Agricola & 4 & 12 & 4 & 20 \\
\hline Napolact & 6 & 4 & & 10 \\
\hline Poiana & 5 & 2 & 1 & 8 \\
\hline Borsec & 2 & 3 & 2 & 7 \\
\hline Dorna & 2 & 2 & 3 & 7 \\
\hline Rom & 2 & 3 & 3 & 7 \\
\hline Zuzu & 2 & 2 & 3 & 6 \\
\hline Covalact & 2 & 2 & 2 & 5 \\
\hline Luca & 2 & 2 & 2 & $\mathrm{X}$ \\
\hline Albalact & 26 & 16 & 19 & $\mathrm{X}$ \\
\hline Other answers** & 78 & 62 & 44 & 7 \\
\hline Total answers & & & \\
\hline
\end{tabular}

* brands indicated by a minimum 5 respondents.

** including some non-indigenues brands.

In the category of alcoholic beverages, it appears, from the number of respondents who indicated among the top three known brands, that the most popular brands are: Timişoreana Ciuc, Bucegi, Cotnari, Ursus, Noroc, Ciucaş. Considering the first nominated brand, the results show that the Cotnari ranks first, followed by Timişoreana Ciuc, Ursus, Noroc.

Of all the respondents. 49 indicated 3brands, 24 indicated 2 brands and 15 indicate 1 brand of alcohol product, 12 of them failing to indicate any brand. There is a higher proportion of those who could indicate atleastone brand of alcoholic beverages, compared to the food productssituation, which reflects a high degree of knowledge of local brands of alcoholic beverages compared to those specific to food products.

Table 3. The most famous Romanian alcoholic beverages brands* (Number of respondents who indicated a particular brand among the top three that come to mind)

\begin{tabular}{|l|c|c|c|c|}
\hline Brand & $\begin{array}{c}\text { As first } \\
\text { option }\end{array}$ & $\begin{array}{c}\text { As second } \\
\text { option }\end{array}$ & $\begin{array}{c}\text { As third } \\
\text { option }\end{array}$ & $\begin{array}{c}\text { \% persons who indicated } \\
\text { brand among the top 3 } \\
\text { known brands in total } \\
\text { number of respondents }\end{array}$ \\
\hline Timişoreana & 15 & 15 & 7 & 37 \\
\hline Ciuc & 13 & 9 & 6 & 28 \\
\hline Bucegi & 8 & 10 & 8 & 26 \\
\hline Cotnari & 16 & 6 & 3 & 23 \\
\hline Ursus & 10 & 12 & 1 & 12 \\
\hline Noroc & 5 & 5 & 2 & \\
\hline
\end{tabular}




\begin{tabular}{|l|c|c|c|c|} 
Ciucaş & 3 & 3 & 4 & 10 \\
\hline Other answers** & 18 & 13 & 18 & $\mathrm{X}$ \\
\hline Total answers & 88 & 73 & 49 & $\mathrm{X}$ \\
\hline
\end{tabular}

* brands indicated by a minimum 5 respondents.

** including some non-indigenues brands.

For the category of cosmetics and personal hygiene, the best known brands (indicated by a minimum of 5 respondents) are: Farmec and Gerovital. It appears that under 50\% of respondents were able to identify at least one brand of Romanian cosmetic products and personal hygiene and only 5 people idicated three brands. It should also be noted that except for the two brands (Farmecand Gerovital), a significant share in total of other mentioned brands was held by foreign brands (over 75\%) which reflects a low level of knowledge of the Romanian brands in this category.

Table 4. The most famous Romanian cosmetics and personal hygiene brands* (Number of respondents who indicated a particular brand among the top three that come to mind)

\begin{tabular}{|l|c|c|c|c|}
\hline \multicolumn{1}{|c|}{ Brand } & $\begin{array}{c}\text { As first } \\
\text { option }\end{array}$ & $\begin{array}{c}\text { As second } \\
\text { option }\end{array}$ & $\begin{array}{c}\text { As third } \\
\text { option }\end{array}$ & $\begin{array}{c}\text { \% persons who } \\
\text { indicated brand } \\
\text { among the top 3 } \\
\text { known brands in total } \\
\text { number of } \\
\text { respondents }\end{array}$ \\
\hline Farmec & 8 & 3 & 1 & 12 \\
\hline Gerovital & 6 & 1 & 1 & 8 \\
\hline Other answers** & 33 & 15 & 3 & $\mathrm{X}$ \\
\hline Total answers & 47 & 19 & 5 & $\mathrm{X}$ \\
\hline
\end{tabular}

* brands indicated by a minimum 5 respondents.

** over $75 \%$ of them fall into the category of foreignbrands.

For cleaning products category, the most famous Romanian brands are Dero and Triumph. Over $40 \%$ of respondents were not able to identify at least one domestic brand of cleaning products. In other category nominations (except Dero and Triumph), 95\% have targeted foreign brands, certifying thus very low level of knowledge of local brands for this product category.

Table 5. The most famous Romanian cleaning productsbrands * (Number of respondents who indicated a particular brand among the top three that come to mind)

\begin{tabular}{|l|c|c|c|c|}
\hline \multicolumn{1}{|c|}{ Brand } & $\begin{array}{c}\text { As first } \\
\text { option }\end{array}$ & $\begin{array}{c}\text { As second } \\
\text { option }\end{array}$ & $\begin{array}{c}\text { As third } \\
\text { option }\end{array}$ & $\begin{array}{c}\text { \% persons who } \\
\text { indicated brand among } \\
\text { the top 3 known } \\
\text { brands in total number } \\
\text { of respondents }\end{array}$ \\
\hline Dero & 12 & 3 & 2 & 17 \\
\hline Triumf & 2 & 3 & & 5 \\
\hline Other answers** & 45 & 23 & 11 & $\mathrm{X}$ \\
\hline Total answers & 59 & 29 & 13 & $\mathrm{X}$ \\
\hline
\end{tabular}

* brands indicated by a minimum 5 respondents.

$* * 95 \%$ of them fall into the category of foreignbrands.

For clothing and footwear categories, awareness of Romanian brands is relatively identical. Only one brand for each category exceeded 5 nominations - Mizar for clothing and Marelbo for footwear. Over $60 \%$ of respondents were not able to identify 
any Romanian brand for the two categories and the category "other answers" (see Tables 6 and 7) hold a significant share of foreign brands. So, in this case too, awareness is extremely low for Romanian brands, respondents indicating eithernolocal brand or confusing them with foreign brands.

Table 6. The most famous Romanian clothing brands* (Number of respondents who indicated a particular brand among the top three that come to mind)

\begin{tabular}{|l|c|c|c|c|}
\hline \multicolumn{1}{|c|}{ Brand } & $\begin{array}{c}\text { As first } \\
\text { option }\end{array}$ & $\begin{array}{c}\text { As second } \\
\text { option }\end{array}$ & $\begin{array}{c}\text { As third } \\
\text { option }\end{array}$ & $\begin{array}{c}\text { \% persons who } \\
\text { indicated brand among } \\
\text { the top 3 known } \\
\text { brands in total number } \\
\text { of respondents }\end{array}$ \\
\hline Mizar & 14 & - & - & 14 \\
\hline Other answers** & 25 & 17 & 5 & $\mathrm{X}$ \\
\hline Total answers & 39 & 17 & 5 & $\mathrm{X}$ \\
\hline
\end{tabular}

* brands indicated by a minimum 5 respondents.

$* * 70 \%$ of them fall into the category of foreignbrands.

Table 7. The most famous Romanian footwear brands* (Number of respondents who indicated a particular brand among the top three that come to mind)

\begin{tabular}{|l|c|c|c|c|}
\hline \multicolumn{1}{|c|}{ Brand } & $\begin{array}{c}\text { As first } \\
\text { option }\end{array}$ & $\begin{array}{c}\text { As second } \\
\text { option }\end{array}$ & $\begin{array}{c}\text { As third } \\
\text { option }\end{array}$ & $\begin{array}{c}\text { \% persons who } \\
\text { indicated brand among } \\
\text { the top 3 known } \\
\text { brands in total number } \\
\text { of respondents }\end{array}$ \\
\hline Marelbo & 14 & - & - & 14 \\
\hline Other answers** & 19 & 13 & 5 & $\mathrm{X}$ \\
\hline Total answers & 33 & 13 & 5 & $\mathrm{X}$ \\
\hline
\end{tabular}

* brands indicated by a minimum 5 respondents.

$* *$ over $75 \%$ of them fall into the category of foreignbrands.

Allview and Arctic brands are the only Romanian electronics and home appliances brands known by the respondents. More than half of the respondents were not able to identify at least one brand for this product category. Other mentioned brands are foreign or, where appropriate, brands of local distributors of electronic products and home appliances.

Table 8. The most famous Romanian electronics and home appliances brands* (Number of respondents who indicated a particular brand among the top three that come to mind)

\begin{tabular}{|c|c|c|c|c|}
\hline Brand & $\begin{array}{l}\text { As first } \\
\text { option }\end{array}$ & $\begin{array}{l}\text { As second } \\
\text { option }\end{array}$ & $\begin{array}{l}\text { As third } \\
\text { option }\end{array}$ & $\begin{array}{l}\% \text { persons who } \\
\text { indicated brand among } \\
\text { the top } 3 \text { known } \\
\text { brands in total number } \\
\text { of respondents }\end{array}$ \\
\hline Allview & 15 & 1 & - & 16 \\
\hline Arctic & 7 & - & 1 & 8 \\
\hline Other answers** & 22 & 18 & 9 & $\mathrm{X}$ \\
\hline Total answers & 44 & 19 & 10 & $\mathrm{X}$ \\
\hline
\end{tabular}


For car category, $83 \%$ indicated Romanian brand Dacia, the remaining respondents indicating foreign brands $(6 \%)$ or, where applicable, not indicating any brand.

\section{Conclusions}

Results of research referring to awareness of Romanian brands in general and by product category certifies a lesser degree of knowledge at least for certain product categories.

The best known Romanian brands, whatever category of products / services to which they relate, ranked according to the number of respondents that indicated in the top three known brands, are: Dacia, Pambac, Agricola, Cotnari, Timişoreana, Bucegi Napolact, Ursus, Ciuc, Farmec, Dedeman, Luca, Poiana, Covalact.

In some product categories, given the same indicator, the best known brands are: Pambac, Agricola, Napolact, Poiana, Borsec, Dorna, Rom, Zuzu, Covalact, Luca and Albalact for food products; Timişoreana, Ciuc, Bucegi, Cotnari, Ursus, Noroc and Ciucaş for alcoholic beverages; Farmec and Gerovital for cosmetics and personal hygiene; Dero and Triumph for cleaning products; Mizar for clothing; Marelbo for footwear; Allview and Arctic for electronics and home appliances; Dacia for cars.

For the studiedproduct categories, the greatest degree of knowledge of local brands are found in alcoholic beverages and cars (in the latter case, given the share respondents who know only Romanian brand Dacia, compared with the share of those who indicated minimum a local brand for this product categories), followed by food products. On the other product categories there is a low degree of knowledge of local brands, respondents either could not show any brand or confusing the Romanian with foreign brands.

Given the exploratory dimension of conductedresearch, the results can form hypotheses for future research on representative samples of regional, national, etc., in which case, if they are confirmed, may underlie decisions to improve the communication process of local companies managingthe awareness of their brands.

\section{References}

Dătculescu, P. (2012), Cercetarea practică de marketing, Editura Brandbuilders Grup, Bucureşti.

Kotler P., Pfoertsch W. (2011), B2B Brand Management, Editura Brandbuilders Grup, București, after Kotler P., Pfoertsch W. (2006), B2B Brand Management, Spinger-Verlag, Berlin.

Kumar V., Aaker, D.A., Day G.S. (1999), Essentials of Marketing research, John Wiley \& Sons, Inc., New York Chichester Weinheim Brisbane Singapore Toronto.

Pringle H., Field, P. (2011), Strategii pentru brandingul de success. Notorietatea şi longevitatea unei mărci, Editura Polirom Iaşi, after Prongle H., Field, P (2008) Brand Immortality. How Brands Can Live Long and Prosper, Kogan Page Limited, London.

Peter, J.P. \& Olson, J.C. (2008), Consumer Behavior\& Marketing Strategy, International Edition, McGraw-Hill/Irwin.

Săndulescu L. (2015, September, 18), Top 100 cele mai puternice branduri romanesti, Revista Biz available at http://www.revistabiz.ro/top-100-cele-mai-puternicebranduri-romanesti/.

WebFinance, Inc. (2016), Business Dictionary (2016), available at http://www.businessdictionary.com. 